\title{
Türkiye'de Sosyodemografik ve Sosyokültürel Göstergelere Göre Dindarlık Seviyeleri
}

\author{
Zübeyir Nişancı ${ }^{1}$ (D), Ümmügülsüm Aysan² ${ }^{\text {(C) }}$
}

\section{Öz}

Bu makale cinsiyet, eğitim, çalışma durumu, gelir seviyesi, medeni durum gibi sosyodemografik faktörler ile mezhep, dindarlık, yerleşim yeri kökeni gibi sosyokültürel faktörlerin Türkiye'deki bireylerin dindarlık seviyeleri üzerindeki etkilerini nicel analizlerle araştırmayı amaçlamaktadır. Araştırmada Diyanet İşleri Başkanlığı'nın Türkiye İstatistik Kurumu ile gerçekleştirdiği Türkiye'de Dini Hayat Araştırması veri seti kullanılmıştır. Dindarlık seviyesi; katılımcıların kendilerini ne kadar dindar hissettikleri (self evaluation), vakit namazları kılma sıkıkları ve İslam hukukundaki miras paylaşımına bakışları olmak üzere üç şekilde ölçülmektedir. Bu üç farkı dindarlık göstergesinin sosyodemografik ve sosyokültürel faktörler ile ilişkileri, sıralı lojistik regresyon modeli ile analiz edilmektedir. Analiz bulgularında öne çıkan sonuçlar incelendiğinde her üç ölçümde de gelir dışındaki tüm değişkenlerin, dindarlık üzerinde anlamlı etkileri olduğu görülmektedir. Ayrıca ilk iki dindarlık ölçümü (dindarlık seviyesi ve namaz kılma sıklığı) ve onları etkileyen faktörler ile miras dağııımına bakış ve onu etkileyen faktörler arasında anlamlı farklılıklar bulunmuştur.

\section{Anahtar Kelimeler}

Dindarlık seviyeleri •Namaz kılma sıklığı • Miras paylaşımı • Dindarlık ölçümleri

Socio-demographic and Socio-cultural Predictors of Religiosity in Turkey

\section{Abstract}

Using quantitative techniques, this article explores the unique effects of the socio-demographic factors of gender, age, employment status, income level, and marital status, as well as the socio-cultural factors of education, rural-urban background, and religious denomination on levels of religiosity in Turkey. The data set comes from the Survey of Religious Life in Turkey (Türkiye'de Dini Hayat Araşttrması) which was conducted by the Presidency of Religious Affairs (Diyanet İşleri Başkanlığı) in Turkey. This study measures religiosity in three ways. The first includes self-reported religiosity levels. The second is the frequency of performing the five daily prayers. The third measure explores the degree to which participants agree with the Islamic religious practice of inheritance where male descendants inherit twice the amount that females do. Therefore, this article investigates how individuals' socio-demographic profiles and socio-cultural backgrounds predict these three aspects of religiosity in the ordinal logistic regression models. All the variables except income have 
significant effects on religiosity in all three measures. The findings indicate differences to be present in the ways this study's independent variables predict the first two measures of religiosity (self-reported religiosity levels and frequency of daily prayers) compared to how they predict the last (perception of gender differences in inheritance).

\section{Keywords}

Religiosity levels • Frequency of prayer • Inheritance • Religiosity in Turkey • Measures of religiosity

\section{Extended Summary}

Historically, the sociology of religion has dealt mostly with macro sociological problems. Perhaps the most important of these is whether religion has been able to continue its existence and influence as a social institution since modernization. These debates have been shaped around secularization theories and studied extensively up to the 1980s. Later on, as sociologists in general began working on micro-level problems, sociologists of religion started working on micro-issues such as how religion affects individuals' lives. The proliferation of research on micro problems has made ethnographic field research and quantitative methods more visible.

Using quantitative techniques, scientists have tried to answer questions regarding the differences between men and women in their religiosity (Cornwall, 1989; de Vaus \& McAllister, 1987), the differences in religiosity between younger and older adults (Young \& Dowling, 1987), and the effects of education on religion (Albrecht \& Heaton, 1984; Hunsberger, 1978). Similarly, studies examining the effects of religious groups and socialization experiences on individuals' religiosity can be mentioned within this framework.

Understanding religiosity's interactions with individuals' attitudes and behaviors emerged as the next step in quantitative studies on religiosity. In this context, sociologists have studied the effects of religiosity on choosing friends, work, and where to live, as well as political preferences (Malka, Lelkes, Srivastava, Cohen, \& Miller, 2012), voting behaviors (Gerber, Gruber, \& Hungerman, 2016; Miller \& Wattenburg, 1984; Smith \& Walker, 2013), consumption habits (Wilkes, Burnett, \& Howell, 1986), participation levels in volunteer activities (Park \& Smith, 2000; Taniguchi \& Thomas, 2011; Wuthnow \& Hodkinson, 1990; Yeung, 2004), civic engagement levels (Smidth, 1999; Wuthnow, 1999), life satisfaction (Willits \& Crider, 1988), and marital satisfaction (Brown, Orbuch, \& Bauermeister, 2008; Dudley \& Kosinski, 1990; Gaunt, 2006; Hunt \& King, 1974; Shehan, Wilbur, \& Lee, 1990).

Because sociology of religion focuses more on theoretical discussions in Turkey, the number of religious studies conducted using quantitative methods is very low. Moreover, the findings from these few studies have been shared only as descriptive statistics, with no competent studies based on advanced analyses being produced. 
International studies such as the World Values Survey and the International Social Survey Program (ISSP), which enable comparisons around the world, have also included questions about religiosity. However, given that their primary focus is to make international comparisons, their sample sizes are too small to make national analyses. No study is found in Turkey to have examined the effects of socio-economic and socio-demographic variables on religiosity using multivariate techniques.

This article attempts to fill this gap in the literature. The effects of demographic variables such as age, gender, and marital status and social class variables such as education level, rural or city origin, family religiosity, and sect on religiosity in Turkey have been examined using multivariate analysis.

Religiosity is a multidimensional concept encompassing several unique but interrelated dimensions such as religious beliefs, religious practices, and saliency of religion. This article uses three different measures of religiosity: self-reported religiousness, frequency of performing the five daily prayers, and attitudes towards Islamic inheritance where male descendants inherit twice as much as female descendants.

\section{Method}

This article uses the dataset from the Survey of Religious Life in Turkey (SRLT, 2013), which was prepared by the Directorate of Religious Affairs (DRA) with the support of the Turkish Statistical Institute (TURKSTAT). The purpose of SRLT is to determine the religious tendencies of citizens and their reflections on daily life. The sample consists of 21,490 participants and is representative of the entire Turkish population over 18 years of age.

This study is based on the multiple regression analysis, as it aims to reveal the effects of many variables simultaneously and separately. Logistic regression analysis is preferred more than other methods for explaining the relationship between variables in cases where the dependent variable is categorical. Because religiosity is an ordinal dependent variable, this research needs to use ordinal logistic regression analysis. The three models have the same independent variables.

\section{Independent Variables}

Self-rated religiosity has been measured by asking the participants the question, "Which of the following statements reflects your sense of religiosity?" The answers given to this question are (1) "I am quite religious," (2) "I am religious," (3) "I am neither religious nor non-religious," (4) "I am not religious," and (5) "I am not at all religious." In order to convert this to a positive sequence, the values for this variable have been reverse coded. The second dependent variable, the frequency of performing the five daily prayers, is measured through the question, "How often do you perform 
the five daily prayers?" The answers are (1) "Always," (2) "Most of the time," (3) "Occasionally," (4) "Rarely," and (5) "Never." This variable has also been reverse coded. The third dependent variable is measured by the question "Indicate your views on the following statements: When distributing inheritance, I give men a double share." The answer categories are (1) "I agree," (2) "I partially agree," and (3) "I disagree." This item has also been reverse coded so that higher values mean higher religiosity.

\section{Independent Variables}

This research uses the following variables as the independent variables: (1) gender, (2) education, (3) age, (4) employment status, (5) income level, (6) marital status, (7) settlement (rural-urban), (8) family religiousness, and (9) sect.

\section{Findings}

\section{Gender}

Gender appears to have a statistically significant effect on religiosity levels for all three models. Even when controlling the effects of other independent variables, women have been observed to be more religious than men in the first two models. Women define themselves as more religious than men. Similarly, women pray more often than men. Unlike the first two models, however, women are less religious than men when taking attitudes towards inheritance distribution into consideration.

\section{Age}

Age has a positive effect on religiousness. In the first two models, religiosity gradually increases with age. However, the effect of age on attitudes towards inheritance sharing is slightly more limited.

\section{Settlement}

According to the first two models, people living in the city are less religious than those living in rural areas. Indeed, those living in the city feel less religious and pray less frequently than those living in rural areas. However, the third model shows that those who live in rural areas have a more negative attitude toward Islamic inheritance distribution than those living in the city.

\section{Employment Status}

In all three models, those who work actively in a job are less religious than those who do not work. 


\section{Marital Status}

All three models show that married people are more religious than unmarried people are.

\section{Education}

According to the first model, the highest level of religiosity is observed among secondary school graduates, followed by post secondary vocational college and primary school graduates, respectively. Those who have no formal education pray the most frequently, whereas university graduates pray more frequently than high school graduates. Those with no formal education have a more positive attitude towards Islamic inheritance distribution than university graduates.

\section{Family Religiosity}

In all three models, family religiosity appears to have a positive effect on religiosity. As family religiosity increases, participants are more likely to feel religious, pray more frequently, and have a more positive attitude towards Islamic inheritance distribution.

\section{Sect}

According to the regression results, sect has a significant effect on religiousness levels. In all three indicators of religiousness, Hanafi and Shafi'i individuals are more likely to be religious than those from other sects. Shafi'i individuals are the most religious with respect to all three indicators.

\section{Conclusion}

The findings from the three models show level of religiosity in Turkey to not change with respect to income groups. One important finding from this study is that age has significant implications for religious self-assessment and frequency of prayer. Similarly, many studies conducted in Turkey and in the world have shown a positive relationship to exist between age and religiosity (Argue, Johnson, \& White, 1999; Taplamacıoglu, 1962). Consistent with the literature, married people are found to be more religious than unmarried people. Furthermore, family religiosity has a positive effect on religiosity. Another prominent finding from this study is that the factors affecting the attitudes towards heritage shares in Islamic law differ from those that affect the level of self-evaluated religiousness and frequency of prayer. Another result of the research is the significant effect sect has on religiousness. Hanafi and Shafi'i individuals have been found to be more religious than other sects for all three measures. 
Peer-review: Externally peer-reviewed.

Conflict of Interest: The authors have no conflict of interest to declare.

Grand Support: The authors declared that this study has received no financial support.

Hakem Değerlendirmesi: Dış bağımsız.

Çıkar Çatışması: Yazarlar çıkar çatışması bildirmemiştir.

Finansal Destek: Yazarlar bu çalışma için finansal destek almadığını beyan etmiştir.

\section{Türkiye’de Sosyodemografik ve Sosyokültürel Göstergelere Göre Dindarlık Seviyeleri}

Din sosyolojisi, tarihsel olarak ortaya çıkışı itibariyle, daha çok makro sosyolojik sorunlarla ilgilenmiştir. Bu sorunların belki de en önemlisi, dinin toplumsal bir kurum olarak, modernleşme sürecinde varlığını ve etkisini devam ettirip ettiremeyeceğidir. Bu tartışmalar, sekülerleşme teorileri etrafında şekillenmiş ve 1980'lere kadar yoğun bir şekilde incelenmiştir. Sosyoloji disiplininde makro seviyelerde formüle edilip tartışılan soru ve yaklaşımlardan, mikro seviyeleri ilgilendiren sorulara geçişle neredeyse eş zamanlı olarak din sosyolojisinde de mikro alanlara bir yönelim başlamıştır. Örneğin, dinin bireyin hayatındaki iz düşümleri ve etkilerini anlamaya yönelik mikro araştırmalar yaygınlaşmıştır. Mikro konulardaki araştırmaların yaygınlaşması, iki araştırma yönteminin oldukça yaygın bir şekilde kullanılmasıyla daha görünür hale gelmiştir. Bunlardan birincisi, daha çok mikro süreçlerdeki dinamikleri anlamaya yoğunlaşan etnografik alan araştırmaları, ikincisi ise nicel yöntemler ile yapılan araştırmalardır.

Nicel yöntemlerle yapılan ve mikro verilere dayanan araştırmalar, dini bireylerin özelliklerine ve tutumlarına dair değişkenlere indirgeyerek yorumlamaya çalışmıştır (Alston, 1975; Glock, 1962; Glock ve Stark, 1964). Hangi bireylerin daha çok ya da daha az dindar olduğunu ve bu farklılıkların sebeplerini tespit etmeye çalışan araştırmalar, bu türün ilk örneklerindendir. Örneğin, kadınlar ve erkekler arasında dindarlığın farklı olup olmadığ 1 ve varsa bu farklılığın sebeplerinin neler olabileceği (Cornwall, 1989; de Vaus ve McAllister, 1987), yaş gruplarındaki dindarlık farklılıkları (Young ve Dowling, 1987), eğitimin dindarlığı nasıl etkilediği (Albrecht ve Heaton, 1984; Hunsberger, 1978) nicel tekniklerle cevaplanmaya çalışılmıştır. Benzer şekilde bireylerin ait oldukları dini gruplar ve sosyalleşme tecrübelerinin, dindarlıkları üzerindeki etkilerini inceleyen çalışmalar da bu çerçevede zikredilebilir (Kenny, Cromwell ve Vaughan, 1977; Nudelman, 1971; Weigert ve Thomas, 1970). Toplumsal dönüşüm ve dindarlığın dönüşümünü irdeleyen çalışmalar da vardır (Heeles ve ark., 2003). Davie (2012) ise dindarlığın ve kurumsal dini aidiyetin düşüşte olduğu buna mukabil, maneviyatın ve bireysel dindarlığın yükselişte olduğunu iddia etmektedir. $\mathrm{Bu}$ amaçlara yönelik çalışmalar, ağırlıklı olarak Kuzey Amerika ve nispeten daha az sayıda Avrupa ülkelerinde, yapılmıştır. Bu çalışmaların yapıldığı ülkelerin nüfusunun çoğunluğunu Hristiyanlar oluşturmaktadır. 
Dindarlığın bireylerin tutum ve davranışları ile etkileşimini ve bu etkileşimin biçimlerini anlamak, dindarlık üzerine yapılan nicel çalışmaların bir sonraki basamağ1 olarak ortaya çıkmıştır. Bu bağlamda sosyal bilimciler, dindarlığın; arkadaş seçimi, iş seçimi, yaşanılacak mekan seçimi, siyasal tercihler (Malka, Lelkes, Srivastava, Cohen ve Miller, 2012), oy verme davranışları (Gerber, Gruber ve Hungerman, 2016; Miller ve Wattenburg, 1984; Smith ve Walker , 2013), tüketim alışkanlıkları (Wilkes, Burnett ve Howell, 1986), gönüllülük faaliyetlerine katılım seviyeleri (Park ve Smith, 2000; Taniguchi ve Thomas, 2011; Wuthnow ve Hodkinson, 1990; Yeung, 2004), sivil kat1lım düzeyleri (Smidth, 1999; Wuthnow, 1999), yaşam memnuniyeti (Willits ve Crider, 1988), evlilik memnuniyeti (Brown, Orbuch ve Bauermeister, 2008; Dudley ve Kosinski, 1990; Gaunt, 2006; Hunt ve King 1974; Shehan, Wilbur ve Lee, 1990) ve sağl1klı yaşam tercihleri (Ellison ve Levin, 1998; Levin, 1994; Wallace ve Williams, 1997) üzerindeki etkilerini araştırmışlardır. ${ }^{1}$

Türkiye'de din sosyolojisi alanında daha çok teorik tartışmalara odaklanıldığından, Kuzey Amerika ve Avrupa ülkelerinden farklı olarak, nicel yöntemlerle yapılmış dindarlık araştırması sayısı oldukça azdır. Din sosyolojisi alanındaki çalışmaların daha çok nicel yöntemlerin yaygın olarak kullanılmadığı ilahiyat fakültelerinde yapılıyor olması da Türkiye'deki çalışmaların sıklıkla teorik alanda kalmasına neden olmuştur.

Türkiye'deki en geniş kapsamlı dindarlık araştırması, Diyanet İşleri Başkanlığı (DİB) tarafından 2013 yılında yapılan, Türkiye'de Dini Hayat Araştırması' dır (TDHA). Türkiye İstatistik Kurumu (TÜIK) desteğinde Türkiye'nin 81 ilinden tabakalı örneklem yöntemi ile seçilen 21,490 bireyle görüşülerek, temsil kabiliyeti yüksek bir veri seti oluşturulmuştur. Araştırmanın betimleyici bulguları DİB tarafından bir rapor halinde kamuoyu ile paylaşılmıştır (DİB, 2014). Ancak bu araştırmanın verileri kullanılarak yapılmış, regresyon modelleri gibi çok değişkenli analizler ile dindarlık seviyeleri üzerinde etkili olabilecek farklı sosyodemografik ve sosyokültürel faktörlerin etkilerini test etmeye olanak sağlayan çalışmalar, henüz mevcut değildir.

Şimdiye kadar yapılan araştırmaların büyük bir kısmı, genel olarak Türkiye'deki dindarlık seviyelerinin sosyodemografik ve sosyokültürel faktörlerden nasıl etkilendiğini anlamaktan ziyade, (i) Türkiye dışında geliştirilen dindarlık ölçeklerinin Türkiye'deki geçerliliklerini test etmek (Özer, Özbek, Elçi ve Aydın, 2015), (ii) yeni dindarlık ölçekleri geliştirmek (Arslan, 2003; Çayabatmaz, 2016; Ok, 2011; Yapıc1, 2006) veya (iii) belirli sosyal grupların dindarlık seviyelerini belirlemek üzere yapılmıştır.

1 Bu tür çalışmalar "Sociology of Religion", "Journal for the Scientific Study of Religion”, "Review of Religious Research", "Social Compass" gibi günümüz din sosyolojisinde önde gelen akademik dergilerdeki makalelerin ve "Society for the Scientific Study of Religion" ve "Religious Research Association" gibi önde gelen din sosyolojisi konferanslarında sunulan araştırmaların büyük çoğunluğunu oluşturmaktadır. 
Türkiye genelini yansıtmak üzere yapılmış “Türkiye'de Dindarlık” (Akşit, Şentürk, Cengiz ve Küçükural, 2012), "Değiş̧en Türkiye'de Din, Toplum ve Siyaset” (Çarkoğlu ve Toprak, 2000) ve "Türkiye'de Muhafazakarlık: Aile, Din, Devlet, Cinsiyet" (Yılmaz, 2006) gibi akademik çalışmalar da mevcuttur. Ancak bu çalışmaların bulguları sadece betimleyici istatistikler şeklinde paylaşılmış, verilerden çoklu analize dayanan yetkin çalışmalar üretilmemiştir.

Dünya çapında kıyaslamaları da mümkün kılan Dünya Değerler Araştırması (World Values Survey) ve Uluslararası Sosyal Araştırma Programı (ISSP) gibi araştırmalar da dindarlıkla ilgili sorular içermektedir. Ancak bu tür araştırmalar, Türkiye'deki sosyodemografik ve sosyokültürel farklılıkları yansıtabilecek örneklem temsil kabiliyetine sahip değildir. Ayrıca öncelikli hedef uluslararası karşılaştırma yapmak olduğundan, sorular dar kapsamlı olarak tasarlanmıştır. Bu sebeple, genel olarak çoğunluğu Müslüman olan ülkelerde, özelde ise Türkiye'de dindarlık seviyelerini (örneğin namaz kılma gibi dini pratiklerin yapılma sıklığı) ve onları etkileyen faktörleri (örneğin mezhep) tespit etme noktasında yetersiz kalmaktadırlar.

Bu makale, literatürdeki bu boşluğu doldurmak amacıyla TDHA verileri kullanılarak yapılmıştır. Türkiye'de dindarlık seviyelerinin, bireylerin; yaş, cinsiyet ve medeni durum gibi demografik; eğitim seviyesi, kır kent kökeni, aile dindarlı̆ğ ve mezhep gibi kültürel ve gelir seviyesi gibi sosyal sınıf dinamiklerinden nasıl etkilendiği incelenmektedir. Analizlerde çok değişkenli analiz (multivariate) teknikleri kullanılmıştır.

Dindarlık, makalede üç farklı şekilde ölçülmektedir. Bunlardan birincisinde, insanların kendilerini ne kadar dindar hissettikleri bir ölçek üzerinden ölçülmektedir. Çok değişkenli analiz modellerinin ilki, öz değerlendirme şeklinde beyan edilen dindarlık seviyesini etkileyen faktörleri incelemektedir. Ancak öz değerlendirme, sosyal kabul edilebilirlik ön yargısından (social desirability bias) çokça etkilenebildiği için, dindarlık seviyelerini ve onu etkileyen faktörleri her zaman doğru tespit etmekte yeterince güvenilir değildir (Jones ve Elliott, 2017). Bu nedenle öz değerlendirme yanında, katılımcıların dini pratikleri hangi sıklıkla yaptıklarına da bakmak, dindarlık seviyelerinin daha iyi anlaşılması için önemlidir. Bu amaçla, makalede ikinci olarak, yukarıda bahsi geçen sosyodemografik ve sosyokültürel faktörlerin, namaz kılma sıklı̆ı üzerindeki etkileri de incelenmektedir. Son olarak bu çalışma katılımcıların sosyodemografik ve sosyokültürel özelliklerinin, İslam fikhının öngördüğ kadın ve erkek arasındaki miras paylaşım şekline dair tutumlarını nasıl etkilediğini incelemektedir. Öz ve baba bir kardeşler arasında kadının hissesinin erkeğinkinin yarısı olduğu (Aktan, 1991) miras paylaşımı, özellikle günümüzde, toplumsal cinsiyet rolleri gibi seküler kritiklere maruz kalmış fikhi kurallardan biridir. Bu sebeple makalede, dindarlığın miras paylaşımına dair tutuma etkisi, diğer dindarlık göstergelerinden farklı bir durum arz edip etmediği ve sosyodemografik ve sosyokültürel dinamiklerden nasıl etkilendiği de incelenmektedir. 


\section{Veri Seti ve Metot}

Bu makalede 2013 yılında DİB tarafından, TÜİK desteği ile, yapılmış olan TDHA veri seti kullanılmıştır. ${ }^{2}$ TDHA'nın amacı, vatandaşların dini eğilimlerinin ve bunların gündelik hayattaki yansımalarının belirlenmesidir. Araştırma, Türkiye'deki temel demografik parametreler üzerinden temsiliyeti yakalayabilmek için, tabakalı örneklem metodu kullanılarak, 81 ilde ve kır kent farklılıklarını da kapsayacak şekilde tasarlanmıştır. Toplamda, seçilen her örnek haneden 18 ve üzeri yaşta uygun bir fert olacak şekilde, 21,490 katılımcı anketin tamamını cevaplamıştır.

Bu çalışma, birçok değişkenin etkisini aynı anda ve birbirinden ayrışık olarak ortaya koymayı amaçladığından çoklu regresyon analizleri üzerine kuruludur. Araştırmada kullanılan bağımlı değişkenler normal dağılım özellikleri göstermedikleri için sıralı lojistik regresyon analizi kullanılmıştır. Lojistik regresyon analizi, bağımlı değişkenin kategorik olduğu durumlarda değişkenler arasındaki ilişkinin açıklanmasında tercih edilen bir yöntemdir. Bağımsız değişkenlerin çok değişkenli normal dağılıma uygun olması, grupların varyanslarının homojen olması gibi varsayımlara ihtiyaç duymadan kullanılabilmesi bunun en önemli sebeplerindendir (Akın ve Şentürk ,2012).

Araştırmanın konusunu teşkil eden dindarlık bağımlı değişkeni için de lojistik regresyon analizinin kullanılması daha uygundur. Lojistik regresyon analizinin, bağımlı değişkenin özelliğine bağlı olarak, binary lojistik regresyon, multinomial lojistik regresyon ve sıralı lojistik regresyon gibi 3 türü mevcuttur. Dindarlık çok kategorili, niteliksel ve sıralı bir bağımlı değişken olduğu, için bu araştırmada sıralı lojistik regresyon analizinin kullanılması gerekmektedir. Bu analizde bağımsız değişkenler ise sürekli veya kategorik olabilir. Dindarlık üç farklı şekilde ölçüldüğü için, her üç ölçek için birer sıralı regresyon modeli oluşturulmuştur. Üç modeldeki bağımlı değişkenler farklı, bağımsız değişkenler ise ortaktır.

\section{Bağımlı Değişkenler}

$\mathrm{Bu}$ araştırmanın üç farklı bağımlı değişkeni bulunmaktadır. Bunlardan birincisi katılımcıların beyan ettikleri dindarlık seviyeleri, ikincisi vakit namazları kılma sıklıkları ve üçüncüsü ise İslam hukukundaki kadın ve erkek arasındaki miras paylaşımına dair tutumdur. Dindarlık hissi değişkeni öz değerlendirme (self evaluation) şeklinde bir dindarlık ölçümü olup insanların kendilerini ne kadar dindar hissettiklerini ölçmektedir. TDHA' da dindarlık hissi “Aşağıdaki ifadelerden hangisi dindarlık hissinizi yansıtmaktadır?” şeklindeki bir soru ile ölçülmüştür. Bu soruya verilen cevaplar ise (1) “Oldukça dindarım", (2) "Dindarım", (3) "Ne dindarım ne değilim”, (4) "Dindar değilim” ve (5) "Hiç dindar değilim” şeklinde 1'den 5'e giden bir siralama ile

2 TDHA, İstanbul Şehir Üniversitesi'nin Diyanet İşleri Başkanlığı ile yapmıs olduğu özel protokol çerçevesinde, Şehir Üniversitesi'nden sınırlı sayıda akademisyenin kullanımına açılmıştır. Bu çalışmada bu protokol çerçevesinde alınan izinle, TDHA veri setini kullanmaktadır. 
sunulmuştur. Yüksek değerler düşük dindarlığı, düşük değerler ise yüksek dindarlığ1 gösterdiği için, bu madde negatif bir dizilime sahiptir. Bu dizilimi pozitif dizilime çevirmek için bu değişkenin değerleri ters kodlama (reverse coding) ile pozitif dizilime çevrilmiş̧ir. Yeni dizilimde, dindarlık değişkeni 1'den 5'e gitmekte, 1 en düşük seviye olan "Hiç dindar değilim"e karşılık gelirken 5 ise "Oldukça dindarım" seçeneğini ifade etmektedir.

İkinci bağımlı değişken olan vakit namazları kılma sıklığı değişkeni de "Aşağıdaki namazları hangi sıklıkla kılarsınız? Vakit namazlar:" sorusu ile ölçülmüştür. Cevaplar ise (1) "Her zaman", (2) "Çoğunlukla", (3) "Ara sıra", (4) "Nadiren" ve (5) "Hiçbir zaman" seçeneklerinden oluşmaktadır. Dindarlık değişkeninde olduğu gibi, namaz değişkeni de negatif dizilime sahip olduğu için ters kodlama ile pozitif dizilimli hale getirilmiştir. Bu durumda, 1 (hiçbir zaman) en düşük seviyeyi, 5 (her zaman) en yüksek seviyeyi ifade etmektedir.

Araştırmanın üçüncü bağımlı değişkeni olan miras dağılımına dair tutum da TDHA anketindeki "Aşağıdaki ifadelere ilişkin görüşlerinizi belirtiniz" başlıklı soru kapsamındaki "Miras paylaşımında erkeklere iki kat pay veririm" maddesi ile ölçülmüsşür. Cevap kategorileri sırası ile (1) "Katıllyorum", (2) "Kısmen katıllyorum", (3) "Katılmıyorum", (4) "Fikrim yok" ve (5) "Cevap vermek istemiyorum" şeklindedir. Bu cevaplardan son iki tanesi ("fikrim yok" ve "cevap vermek istemiyorum") siralı dizi elde etmek ve regresyon analizlerinde kullanabilmek için kayıp veri olarak kodlanmıştır. Diğer üç cevap kategorisi de ilk iki bağımlı değişkende olduğu gibi, en küçük değerin en düşük dindarlık seviyesini ve en yüksek değerin en yüksek dindarlık seviyesini göstermesi için, ters kodlama yapılarak yeniden kodlanmıştır. Böylece en düşüğü "katılmıyorum" ve en yükseği "katılıyorum" olmak üzere 1'den 3'e gidecek şekilde pozitif dizilimli bir değişken elde edilmiştir.

\section{Bağımsız Değişkenler}

Bu araştırmada (1) cinsiyet, (2) eğitim, (3) yaş, (4) çalışma durumu, (5) gelir seviyesi, (6) medeni durum, (7) yerleşim yeri (kır-kent), (8) aile dindarlığı ve (9) mezhep olmak üzere dokuz ayrı bağımsız değişken kullanılmıştır. Cinsiyet değişkeni için erkekler referans grubu olarak regresyon modellerinde dışarda bırakılmıştır. Yaş değişkeninde farklı yaş grupları arasında doğrusal olmayan farklılıklar olup olmadığını anlamak için dört ayrı yaş grubu kodlanmıştır. Bu yaş grupları (1) 18-24, (2) 25-44, (3) 45-64 ve (4) 65 yaş ve üstü şeklindedir. Regresyon analizlerinde dışarda bırakılan referans grubu "65 yaş ve üstü" dür. Katılımcıların eğitim seviyesi TDHA veri setinde (1) "Bir okul bitirmedi”, (2) "İlkokul”, (3) "İlköğretim/Ortaokul veya Mesleki Ortaokul”, (4) "Lise veya Mesleki Lise”, (5) "2 veya 3 Yıllık Yüksek Okul”, (6) "4 Yıllık Yüksek Okul veya Fakülte", (7) "Yüksek Lisans" ve (8) "Doktora" şeklinde kategorize edilmiştir. Son iki seviye olan "Yüksek Lisans" ve "Doktora" mezunlarının toplamının, 
örneklemin toplamına oran $1 \% 1$ 'in altında olduğundan, anlamlı k1yaslama yapabilmek için bu gruplar "üniversite mezunları" ile birleştirilerek 6 kategorili yeni bir eğitim değişkeni elde edilmiştir. Regresyon analizlerinde en yüksek kategori olan "üniversite mezunları" referans grubu olarak kullanılmıştır.

Gelir getiren bir işte çalışıp çalışmama durumu, veri setinde (1) "çalışan" ve (2) "çalışmayan" şeklinde kodlanmıştır. Regresyon analizlerinde dışarıda bırakılan referans grup "çalışmayan" kategorisidir. Gelir seviyesi değişkeni ise açık uçlu sayısal bir ölçektir ve katılımcıların toplam aylık hane gelirini ifade etmektedir. Belirtilen gelir seviyesi veri setinde sıfır (0) liradan 8,820 liraya kadar çıkmaktadır. Bu aralık büyüklüğü $(8,820)$ regresyon model uyum seviyelerini (model fit) düşürebileceği, regresyon varsayımlarını ihlal edebileceği ve regresyon çarpanlarını (coefficient) çok küçültebileceğinden, gelir değişkeninin doğal logaritması (natural logarithm) alınarak regresyon modellerinde kullanılmıştır.

Katılımcıların medeni durumu, TDHA veri setinde yedi grupta şu şekilde tasnif edilmiştir: (1) "Hiç Evlenmedi”, (2) "Boşandı", (3) “Eşi Öldü”, (4) "Evli, Resmi Nikahlı", (5) "Evli, Dini Nikahlı”, (6) "Evli, Ayrı Yaşıyor”, (7) "Birlikte Yaşıyor”. Bu çalışmada halen evli olup birlikte yaşayanlar diğer bütün medeni durum kategorileri ile kıyaslanmaktadır. Bu amaçla bir tarafta halen evli olup birlikte yaşayanlar ve diğer tarafta ise diğer bütün medeni durum kategorilerinin olduğu bir kukla değişken (dummy variable) oluşturulmuştur. Buna göre "Evli, Resmi Nikahlı" ve "Evli, Dini Nikahlı"lar evli grubunda, diğer bütün kategoriler ise "diğer" grubundadır. Regresyon analizlerinde de referans grubu "diğer" olarak alınmıştır.

Aile dindarlığı, TDHA veri setinde 5 grupta şu şekilde tasnif edilmiş̧ir: (1) "Ailem dindardır", (2) "Ailem oldukça dindardır", (3) "Ailem ne dindardır ne değildir”, (4) “Ailem dindar değildir”, (5) “Ailem hiç dindar değildir”. Dindarlık değişkeninde olduğu gibi, aile dindarlığı değişkeni de negatif dizilime sahip olduğu için ters kodlama ile pozitif dizilimli hale getirilmiştir.

TDHA veri setinde katılımcıların mezhep bilgileri de dokuz kategori ile sunulmuştur. Bu dokuz kategori şunlardır: (1) "Hanefi”, (2) “Şafii”, (3) “Maliki”, (4) "Hanbeli”, (5) "Caferi", (6) "Diğer", (7) "Hiçbiri", (8) "Bilmiyorum" ve (9) "Cevap vermek istemiyorum". Bunlardan son ikisi ("Bilmiyorum" ve "Cevap vermek istemiyorum") kayıp veri olarak kaydedilmiştir. Geri kalan yedi kategoriyi de anlamlı bir şekilde kıyaslanabilecek yapıya kavuşturmak için mezhep değişkeni üç kategoriye indirilmiştir. Bunlardan birincisi (1) "Hanefi", ikincisi (2) "Şafii" ve üçüncüsü de (3) "diğer"dir. Üçüncü grup olan "diğer” asıl değişkendeki "Maliki”, "Hanbeli”, "Caferi”, "Diğer”, ve "Hiçbiri" kategorilerinin birleştirilmesi ile elde edilmiştir. Regresyon analizlerinde "diğer" kategorisi referans grup olarak dışarda bırakılarak, Hanefi ve Şafii olan katılımcılarla kıyaslanmıştır. 


\section{Bulgular}

\section{Betimleyici İstatistikler}

Tablo 1, TDH araştırmasına katılan 18 yaş ve üstü bireylerin temel özelliklerini göstermektedir. Buna göre katılımcıların \%46'sı erkek \%54'ü kadındır. Yaş kategorileri incelendiğinde \%9'u 18-24 yaş grubunda, \%21'i 25-44 yaş grubunda \%23'ü 45-64 yaş grubunda ve \%19'u 65 yaş ve üstü yaş grubundadır. Eğitim seviyesi açısından incelendiğinde katılımcıların yaklaşık \%46’sı ilkokul mezunudur. Bu grubu \%20 ile lise mezunları takip etmektedir. Yüksekokul mezunu sayısı ise $\% 5$ ile en düşük kategoriyi oluşturmaktadır. Ankete katılanların \%37'si bir işte çalışmakta, \%63'ü ise çalışmamaktadır. Ankete katılanlar 18 yaş ve üstü grup olduğundan $\% 80$ gibi yüksek bir kesimi evli bulunmaktadır. Katılımcılardan \%78'i Hanefi, \%11'i Şafii, \%10'u ise diğer mezheplere mensuptur. Katılımcıların aylık geliri ise 2014 yılında 1,351 Türk lirasıdır.

Tablo 1

Katılımcıların Temel Özellikleri

\begin{tabular}{|c|c|c|c|c|}
\hline & & $\%$ & Ortalama & Std. $S$. \\
\hline \multirow{2}{*}{ Cinsiyet } & Erkek & 45,6 & - & - \\
\hline & Kadın & 54,4 & - & - \\
\hline \multirow{4}{*}{ Yaş } & $18-24$ & 8,6 & - & - \\
\hline & $25-44$ & 21,1 & - & - \\
\hline & $45-64$ & 22,7 & - & - \\
\hline & 65 ve üstü & 18,5 & - & - \\
\hline \multirow{6}{*}{ Ĕgitim } & Bir Okul bitirmedi & 6,3 & - & - \\
\hline & İlkokul & 45,5 & - & - \\
\hline & Ortaokul & 15,8 & - & - \\
\hline & Lise & 19,7 & - & - \\
\hline & Yüksekokul & 4,9 & - & - \\
\hline & Üniversite & 7,8 & - & - \\
\hline \multirow{2}{*}{ İș durumu } & Çalışan & 36,8 & - & - \\
\hline & Çalışmayan & 63,2 & - & - \\
\hline \multirow{2}{*}{ Medeni Durum } & Evli değil & 19,8 & - & - \\
\hline & Evli & 80,2 & - & - \\
\hline \multirow{2}{*}{ Yerleşim } & Kir & 31,9 & - & - \\
\hline & Kent & 68,1 & - & - \\
\hline \multirow{5}{*}{ Aie Dindarlığı } & Ailem oldukça dindardır & 26,4 & - & - \\
\hline & Ailem dindardır & 66,6 & - & - \\
\hline & Ailem ne dindardır, ne dindar değildir & 6,1 & - & - \\
\hline & Ailem dindar değildir & 0,6 & - & - \\
\hline & Ailem hiç dindar değildir & 0,2 & - & - \\
\hline \multirow{3}{*}{ Mezhep } & Hanefi & 77,5 & - & - \\
\hline & Şafii & 11,4 & - & - \\
\hline & Diğer & 10,1 & - & - \\
\hline \multicolumn{2}{|l|}{ Gelir } & - & 1351 & 977 \\
\hline
\end{tabular}


Şekil 1 Türkiye geneli için dindarlık öz değerlendirmelerini göstermektedir. Buna göre Türkiye'de bireylerin büyük çoğunluğu kendilerini dindar (\%70) ya da oldukça dindar (\%19,9) olarak tanımlamaktalar. Bu durumda kendilerini en azından dindar olarak tanımlayanlar Türkiye toplumunun \%90'ıdır. Dindar değilim ya da hiç dindar değilim diyenlerin toplamı ise ancak $\% 1$ civarındadır. Toplumun yaklaşık $\% 11$ ' $\mathrm{i}$ kendisini ortada (ne dindar ne de değil) görmektedir. Şekil l'e bakıldığında kadınlar ve erkekler arasında dindarlık öz değerlendirmeleri arasında farklılıklar olduğu görülmektedir. Aradaki fark çok yüksek olmasa da kadınların erkeklerden daha dindar olduklarını söylenebilir. Örneğin, "oldukça dindarım" diyen erkeklerin oranı \%18,8 iken, bu oran kadınlar için \%20,8'dir. Benzer bir farklılık "dindarım” diyenler için de geçerlidir.

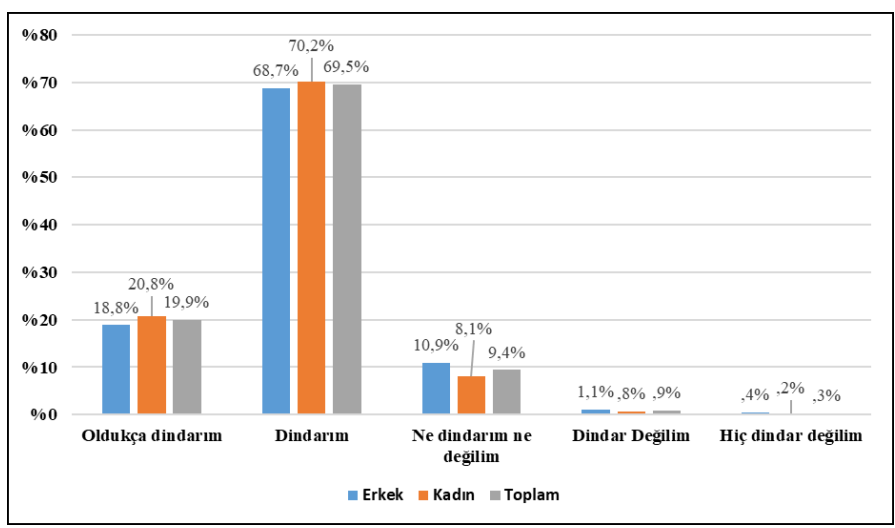

Şekil 1. Cinsiyete göre dindarlık özdeğerlendirmesi.

Not. Şekilde görülen farklılıklar Ki-Kare testi sonuçlarına göre $p<0,001$ seviyesinde istatistiksel olarak anlamlıdir.

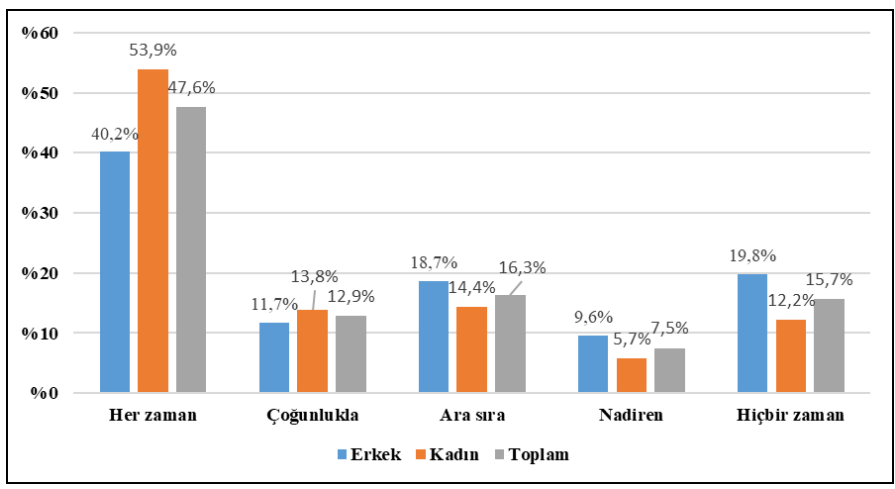

Şekil 2. Cinsiyete göre beş vakit namaz kılma sıklığı.

Not. Şekilde görülen farkl11ıklar Ki-Kare testi sonuçlarına göre $p<0,001$ seviyesinde istatistiksel olarak anlamlıdir. 
Şekil 2, Türkiye genelinde vakit namazı kılma oranlarını göstermektedir. Buna göre katılımcıların yarıya yakını (\%47), her zaman beş vakit namaz kıldıklarını belirtmişlerdir. Hiçbir zaman namaz kılmadıklarını beyan edenlerin oranı \%15,7'dir. Bu durumda her zaman namaz kılanlar hiçbir zaman namaz kılmayanların tam olarak üç katına tekabül etmektedir. Geri kalan \%36,7'lik kesim ise düzensiz olarak (nadiren, ara sira veya çoğunlukla) namaz kıldıklarını ifade etmişlerdir.

Şekil 2'de kadınlar ve erkekler arasında vakit namazı kılma sıklığında farklılıklar olduğu görülmektedir. Zira genel olarak kadınlar erkeklerden daha yüksek oranlarda sürekli namaz kılmaktadırlar. Kadınların \%53,9'u her zaman namaz kıldıklarını ifade ederken, erkeklerde bu oran \%40'a kadar düşmektedir. Aynı şekilde "hiçbir zaman namaz kılmıyorum" diyen kadınların oranı \%12,2 iken, bu oran erkekler için \%20'dir. Bu durumda erkekler arasında her zaman namaz kılanların oranı, hiçbir zaman namaz kılmayanların yaklaşık iki katı iken; kadınlar arasında her zaman namaz kılanların oranı, hiçbir zaman namaz kılmayanların yaklaşık 4 buçuk katıdır. Namaz kılma oranları cinsiyet açısından değerlendirildiğinde, kadınlar erkeklere göre daha dindar görünmektedirler.

Bu çalışmada kullanılan dindarlık ölçümlerinin üçüncüsü olan İslam hukukundaki miras paylaşımına bakışın dağılımı, Şekil 3'te verilmiş̧tir. Dindarlık öz değerlendirmesi ve namaz kılma sıklığındaki tablonun aksine, Türkiye toplumunun büyük çoğunluğu dindarlık olarak algılanabilecek seçeneğin karşıtını tercih etmekte, yani bu uygulamaya katılmadığını beyan etmektedir. Katılımcıların yaklaşık olarak dörtte üçü $(\% 73,8)$ bu uygulamayı doğru bulmadıklarını belirtmektedir. Yaklaşık yüzde beşlik $(\% 4,8)$ bir kesim ise kısmen katıldığını beyan etmiştir. Yalnızca yaklaşık beşte bir oranındaki katılımcı miras paylaşımındaki farklılı̆̆ doğru bulduğunu belirtmiştir.

Miras paylaşımına bakışta da kadınlar ve erkekler arasında farklıklar olduğu gözlemlenmiştir. Dindarlık öz değerlendirmesi ve namaz kılma sıklığına göre kadınlar daha dindar bir görünüm arz ederken, miras paylaşımına bakışta bu durum erkeklerin lehine değişmektedir. Erkeklerin \%70,6'sı erkeklerin mirastan 2 kat pay almasını doğru bulmadığını söylerken, kadınlarda bu oran \%76,5'e çıkmaktadır. Miras dağılımını doğru bulan erkeklerin oran $\% 23,6$ iken, kadınlarda bu oran $\% 19,6^{\prime}$ dır. $^{3}$

3 Diğer bağımsız değişkenlere göre dindarlık oranları için Diyanet İşleri Başkanlığı, Türkiye Dini Hayat Araştırması'na başvurulabilir. 


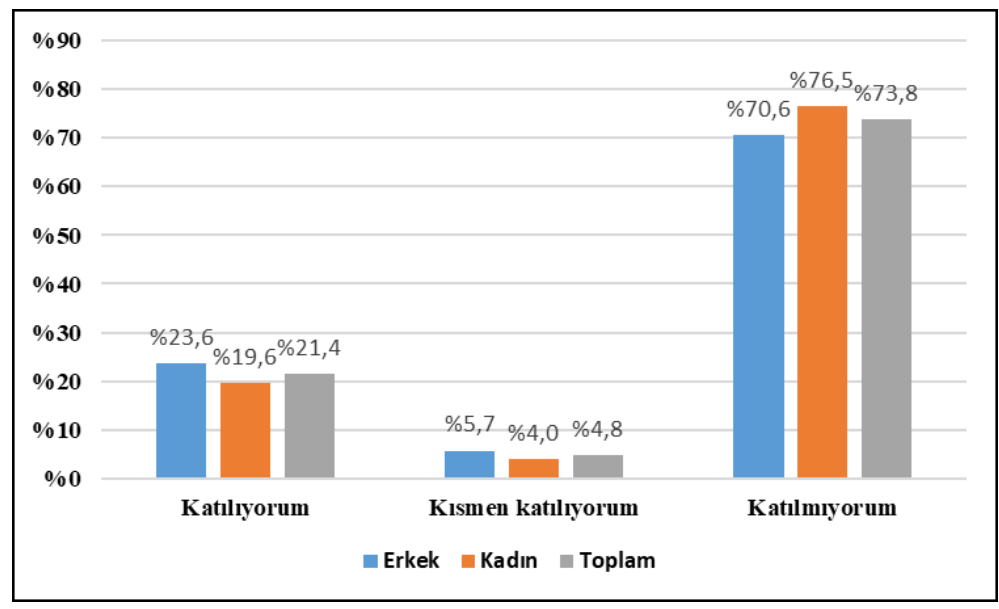

Şekil 3. Cinsiyete göre miras paylaşımına bakış.

Not. Şekilde görülen farklılıklar Ki-Kare testi sonuçlarına göre $p<0,001$ seviyesinde istatistiksel olarak anlamlıdır.

\section{Parametrelerin Yorumlanması}

Tablo 2, dindarlık öz değerlendirmesi, vakit namaz kılma sıklığ1 ve miras dağılımına bakışı, yukarıda belirtilen bağımsız değişkenlerin etkisine birlikte bakarak tahmin eden, üç ayrı sıralı regresyon modelinin sonuçlarını içermektedir. Tablodaki verilere göre 9 bağımsız değişkenden 8'inin belirli kategorileri itibariyle anlamlı çıktığ1 görülmektedir. Gelir dindarlığın her üç göstergesinde de anlamlı bir etkisi olmayan tek değişkendir.

Tablo 2

Dindarlık Seviyesi, Namaz Kılma Sıklı̆̆ ve Miras Paylaşımına Akışını Tahmin Eden Sıralı Regresyon Modelleri

\begin{tabular}{|c|c|c|c|c|c|c|c|c|c|}
\hline & \multicolumn{3}{|c|}{ Dindarlık Seviyesi } & \multicolumn{3}{|c|}{ Namaz Kılma Siklığ 1} & \multicolumn{3}{|c|}{ Miras Paylaşımı } \\
\hline & Estimate & S.E & Sig. & $\begin{array}{l}\text { Esti- } \\
\text { mate }\end{array}$ & S.E & Sig. & Estimate & S.E & Sig. \\
\hline Cinsiyet (Kadın) & .269 & .049 & $* * *$ & .425 & .036 & $* * *$ & -.446 & .044 & $* * *$ \\
\hline Cinsiyet (Erkek) & $0^{\mathrm{a}}$ & & & $0^{\mathrm{a}}$ & & & $0^{\mathrm{a}}$ & & \\
\hline Yaş Grubu: 18-24 & -.753 & .102 & $* * *$ & -1.524 & .078 & $* * *$ & .010 & .093 & \\
\hline Yaş Grubu: 25-44 & -.487 & .081 & $* * *$ & -1.141 & .063 & $* * *$ & .168 & .071 & $*$ \\
\hline Yaş Grubu: 45-64 & -.314 & .077 & $* * *$ & -.602 & .061 & $* * *$ & .079 & .068 & \\
\hline Yaş Grubu: 65 ve üstü & $0^{\mathrm{a}}$ & & & $0^{\mathrm{a}}$ & & & $0^{\mathrm{a}}$ & & \\
\hline $\begin{array}{l}\text { Eğitim: Bir Okul bitir- } \\
\text { medi }\end{array}$ & .201 & .122 & & .300 & .092 & $* * *$ & .215 & .106 & $*$ \\
\hline Eğitim: İlkokul & .221 & .089 & $*$ & .127 & .063 & $*$ & -.069 & .079 & \\
\hline Eğitim: Ortaokul & .277 & .094 & $* *$ & -.037 & .067 & & -.074 & .084 & \\
\hline Eğitim: Lise & .167 & .087 & & -.144 & .062 & $*$ & -.057 & .078 & \\
\hline Eğitim: Yüksekokul & .245 & .114 & $*$ & .039 & .081 & & -.008 & .102 & \\
\hline Eğitim: Üniversite & $0^{\mathrm{a}}$ & & & $0^{\mathrm{a}}$ & & & $0^{\mathrm{a}}$ & & \\
\hline
\end{tabular}




\begin{tabular}{|c|c|c|c|c|c|c|c|c|c|c|c|c|}
\hline \multicolumn{2}{|c|}{ Çalışan } & -.154 & .053 & $* *$ & & -.422 & .038 & $* * *$ & & -.151 & .047 & $* *$ \\
\hline \multicolumn{2}{|c|}{ Çalışmayan } & $0^{\mathrm{a}}$ & & & & $0^{\mathrm{a}}$ & & & & $0^{\mathrm{a}}$ & & \\
\hline \multicolumn{2}{|c|}{ Gelir (ln) } & .055 & .039 & & & -.018 & .029 & & & .014 & .035 & \\
\hline \multicolumn{2}{|c|}{ Medeni durum: Evli } & .317 & .059 & $* * *$ & & .286 & .043 & $* * *$ & & .133 & .055 & $*$ \\
\hline \multicolumn{2}{|c|}{ Medeni durum: Evli değil } & $0^{\mathrm{a}}$ & & & & $0^{\mathrm{a}}$ & & & & $0^{\mathrm{a}}$ & & \\
\hline \multicolumn{2}{|c|}{ Yerleşim Birimi: Kent } & -.207 & .048 & $* * *$ & & -.135 & .035 & $* * *$ & & .158 & .043 & $* * *$ \\
\hline \multicolumn{2}{|c|}{ Yerleşim Birimi: Kır } & $0^{\mathrm{a}}$ & & & & $0^{\mathrm{a}}$ & & & & $0^{\mathrm{a}}$ & & \\
\hline \multicolumn{2}{|c|}{ Aile dindarlı̆̆ 1} & 3.680 & .044 & $* * *$ & & .796 & .028 & $* * *$ & & .293 & .033 & $* * *$ \\
\hline \multicolumn{2}{|c|}{ Mezhep: Hanefi } & .519 & .096 & $* * *$ & & 1.408 & .072 & $* * *$ & & .522 & .107 & $* * *$ \\
\hline \multicolumn{2}{|c|}{ Mezhep: Şafii } & .645 & .116 & $* * *$ & & 2.325 & .089 & $* * *$ & & 1.047 & .119 & $* * *$ \\
\hline \multicolumn{2}{|c|}{ Mezhep: Diğer } & $0^{\mathrm{a}}$ & & & & $0^{\mathrm{a}}$ & & & & $0^{\mathrm{a}}$ & & \\
\hline \multirow[t]{4}{*}{ Eşik } & 1 & 6.107 & .405 & $* * *$ & 1 & 1.961 & .258 & $* * *$ & 1 & 2.955 & .322 & $* * *$ \\
\hline & 2 & 9.060 & .360 & $* * *$ & 2 & 2.551 & .258 & $* * *$ & 2 & 3.234 & .322 & $* * *$ \\
\hline & 3 & 13.021 & .364 & $* * *$ & 3 & 3.529 & .259 & $* * *$ & & & & \\
\hline & 4 & 18.699 & .383 & $* * *$ & 4 & 4.188 & .259 & $* * *$ & & & & \\
\hline
\end{tabular}

Not. Tabloda görülen farklılıklar $* * * p<.001, * * p<.010$ ve $* * * p<.050$ seviyesinde istatistiksel olarak anlamlıdır.

\section{Cinsiyet}

Cinsiyetin, her üç modelde de, dindarlık seviyeleri üzerinde istatistiksel olarak anlamlı bir etkisi olduğu görülmektedir. Diğer bağımsız değişkenlerin etkisi kontrol edildiğinde dahi ilk iki modelde kadınların erkeklere göre daha dindar olduğu görülmüştür. Kadınların kendilerini, erkeklere göre daha dindar olarak tanımladığı görülmüştür. Benzer, şekilde kadınlar erkeklere göre daha sık namaz kılmaktadır. Miras paylaşımına bakış açısından değerlendirildiğinde ise, ilk iki modelden farklı olarak, kadınlar erkeklere oranla daha az dindar bir görünüm arz etmektedir.

\section{Yaş}

Yaşın da öngörülebildiği üzere, dindarlık üzerinde pozitif bir etkisi vardır. İlk iki modelde, yaş grubu arttıkça dindarlık kademeli olarak artmaktadır. Ancak yaşın miras paylaşımına bakıştaki etkisi biraz daha sınırlıdır. Miras paylaşımına bakışta, yalnızca 25-44 yaş grubu, referans grup olan 65 yaş ve üstü grubundan istatistiksel olarak anlamlı bir farklılık göstermektedir. Bu yaş grubu, İslam hukukuna uygun miras paylaşımına, referans gruba kıyasla daha olumlu bakmaktadır.

\section{Yerleşim Yeri}

İlk modele göre yaşayanlar kırsal alanlarda yaşayanlara göre daha az dindardır. Nitekim şehirde yaşayanlar, kırda yaşayanlardan daha az dindar hissetmekte (-0.207) ve daha seyrek namaz kılmaktadır (-0.135). Ancak üçüncü model, kırda yaşayanların miras paylaşımına bakışta şehirde yaşayanlara (0.158) göre daha olumsuz bir bakış açısına sahip oldukları görülmektedir. Regresyon modelinden bağımsız olarak, betimleyici tablolarda da kır ve kent arasında bu şekildeki bir fark ortaya çıktığı görülmektedir. Tablo 
3'e göre kırda yaşayanlar ile şehirde yaşayanlar arasında çok küçük de olsa istatistiksel olarak anlamlı bir farklılık görülmektedir. Kırda yaşayanların \%21,4'ü İslami miras paylaşımını doğru bulurken kenttekilerin \%21,5’i bunu doğru bulmaktadır. Bu fark, "Katılmıyorum" diyenlerde biraz daha belirgindir. Bu dağılımı doğru bulmayanların oranı kırda yaşayanlar için \%74,6 iken şehirde yaşayanlar için \%73,3’tür.

Tablo 3

Íslam Hukukundaki Miras Paylaşımına Bakışın Kır ve Kente Göre Dağılımı (\%)

\begin{tabular}{|l|c|c|c|}
\hline & Kir & Kent & Toplam \\
\hline Katıliyorum & 21,4 & 21,5 & 21,4 \\
\hline Kismen katıliyorum & 4,0 & 5,2 & 4,8 \\
\hline Katılmiyorum & 74,6 & 73,3 & 73,8 \\
\hline
\end{tabular}

Not. Tabloda görülen farklılıklar Ki-Kare testi sonuçlarına göre $p<0,001$ seviyesinde istatistiksel olarak anlamlıdır.

\section{Çalışma Durumu}

Bir işte aktif olarak çalışanlar, çalışmayanlara göre daha az dindardırlar. Her üç modelde de benzer bir durum olduğu görülmektedir. Çalışanlar kendilerini çalışmayanlara göre daha az dindar hissetmekte (-0.154) ve daha seyrek namaz kılmaktadırlar (-0.422). Benzer şekilde İslami miras paylaşımına, çalışanların olumlu yaklaşma ihtimali, çalışmayanlara göre daha düşüktür (-0.151).

\section{Medeni Durum}

Her üç model de evlilerin, evli olmayanlara kıyasla daha dindar olduğunu göstermektedir. Evlilerin kendilerini dindar hissetme ihtimali, referans kategorisi evli olmayanlara göre daha yüksektir (0.317). Namaz kılma sıklığı açısından incelendiğinde regresyon sonuçlarına göre evlilerin daha sık namaz kılma ihtimali, evli olmayanlara göre daha yüksektir (0.286). Benzer şekilde, evlilerin İslam hukukuna uygun miras paylaşımına olumlu bakma ihtimalleri, evli olmayanlara kıyasla daha yüksektir (0.133).

\section{Ĕgitim}

Regresyon sonuçlarına göre Türkiye'de eğitimin dindarlık üzerinde doğrusal olmayan bir görüntü arz ettiği görülmektedir. Birinci modele göre, en yüksek dindarlık seviyesi ortaokul düzeyinde gözlemlenirken, ortaokul mezunlarını sırasıyla yüksekokul ve ilkokul mezunları takip etmektedir. Referans kategorisi olan üniversite mezunlarına kıyasla, ortaokul mezunları (0.277), yüksekokul mezunları (0.245) ve ilkokul mezunlarının (0.221) kendilerini daha yüksek ihtimalle dindar olarak tanımlamaktadırlar. Daha az dindar oldukların beyan eden bir okul bitirmeyen ve lise mezunları ile üniversite mezunları arasında istatistiksel olarak anlamlı bir fark bulunmamaktadır. İkinci modele göre bütün eğitim grupları içinde en az vakit namaz kılma ihtimali, lise mezunlarına aittir. Lise mezunlarının namaz kılma sıklığ $1(-0,144)$, referans grup olan üniversite mezunlarına göre daha düşüktür. Üniversite mezunları, yüksekokul ve 
ortaokul mezunları ise birlikte en düşük namaz kılma sıklığı belirten ikinci grubu oluşturmaktadır. Ancak bu üç grup arasında anlamlı bir fark bulunmamaktadır. En sık namaz k1lan grup "bir okul bitirmeyenler"dir (0.300). İlkokul mezunları da üniversite mezunlarına kıyasla daha s1k namaz k1ma ihtimaline sahiptirler (0.127). Miras paylaşımına bakışta ise sadece "bir okul bitirmeyenler" ile referans grup olan "üniversite mezunları" arasında anlamlı bir fark olduğu görülmektedir. "Bir okul bitirmeyenler"in miras paylaşımına olumlu bakma ihtimali, üniversite mezunlarının olumlu bakma ihtimalinden daha yüksektir (0.215). Diğer gruplar ile referans kategorisi arasında ise anlamlı bir fark bulunmamaktadır.

\section{Aile Dindarlı̆g}

Her üç modelde de, aile dindarlığının, dindarlığ 1 pozitif olarak etkilediği görülmektedir. Ailesi ile ilgili olarak daha yüksek dindarlık seviyeleri beyan eden katılımcılar, ele alınan üç modelde de kendileriyle ilgili olarak daha yüksek dindarlık seviyeleri beyan etmektedirler. Aile dindarlığı arttıkça, katılımcıların kendilerini daha dindar hissetme ihtimalleri (3.680), daha s1k namaz kılma ihtimalleri (0.796) ve İslami miras paylaşımına olumlu bakma ihtimalleri (0.293) artmaktadır.

\section{Mezhep}

Regresyon sonuçlarına göre mezhebin dindarlık seviyeleri üzerinde belirgin bir etkisi olduğu görülmektedir. Her üç dindarlık göstergesinde de Hanefi ve Şafii olanların dindar olma ihtimali, "diğer" mezheplerden olanlara göre daha yüksektir. Şafiilerin, her üç göstergeye göre de en dindar mezhep grubu olduğu görülmektedir. Hanefilerin kendilerini dindar olarak tanımlama ihtimali "diğer" kategorisine referansla daha yüksektir (0.519). Aynı şekilde Şafiilerin kendilerini dindar olarak tanımlama ihtimali "diğer" referans grubuna göre daha yüksektir (0.645). En büyük fark ise namaz k1lma sıklığında görülmektedir. Şafiilerin namaz kılma sıklığı, referans grubu olan "diğer" mezhep kategorilerine göre daha yüksektir (2.325). Yine aynı şekilde Hanefilerin daha sık namaz kılma ihtimali "diğer" mezhepler kategorisine göre daha yüksektir (1.408). Şafilerin İslami miras paylaşımına olumlu bakma ihtimali "diğer" mezhepler kategorisine mensup bireylerinkine göre daha yüksektir (1.047). Yine Hanefilerin İslami miras paylaşımına olumlu bakma ihtimali "diğer" mezhepler kategorisine mensup bireylerinkine göre daha yüksektir $(0.522)$.

\section{Tartışma ve Sonuç}

Dindarlık seviyesinin, her üç ölçüm türünde de gelir gruplarına göre değişmemesi, Türkiye'de dindarlığın ekonomik sınıf yapısına dayalı bir olgu olmadığını göstermektedir. Ancak şunu da göz önünde bulundurmak gerekir ki, Türkiye'de yapılan anket çalışmalarında genellikle gelir seviyeleri olduğunun altında beyan edilmektedir 
(Tosuner ve Demir, 2008). Bu durum, daha çok üst gelir gruplarının tespitini zorlaştırmakta ve böylece gelir değişkeninin, diğer sosyal olgularda olduğu gibi, dindarlığa etkisinin de güvenilir bir şekilde istatistiki metotlarla analizini güçleştirmektedir. Dolayısı ile ya dindarlıkla ilgili nicel araştırmalarda ekonomik durumu ölçen araçlar iyileştirilmeli ya da farklı araştırma metotları (alan araştırması vb.) uygulanmalıdır.

Dindarlık öz değerlendirmesi ve namaz kılma sıklığı üzerinde yaşın önemli etkileri olduğu, araştırmanın öne çıkan bulgularındandır. Türkiye'de ve dünyada yaş ve dindarlık arasında pozitif bir ilişki olduğunu gösteren araştırmalar mevcuttur (Argue, Johnson ve White, 1999; Taplamacıoğlu, 1962). Bu araştırma da Türkiye genelinde, yaş ve dindarlık arasında pozitif bir ilişki olduğunu göstermektedir. Beyan edilen dindarlık seviyesi ve namaz kılma sıklığının yaş grubu yükseldikçe düzenli olarak arttığı görülmektedir. Ancak bu bulgulara bakarak, nesiller arası dindarlık farklılı̆̆1 olduğunu söylemek ve dolayısı ile Türkiye toplumunun giderek sekülerleştiğini ileri sürmek kolay değildir. Benzer şekilde yaş arttıkça insanların dindarlaştığı gibi bir kanaate de sadece buradaki veriler 1şı̆̆ında ulaşamayız. Zamanla toplumun genel olarak dindarlık seviyesinin azalıp azalmadığını görebilmek ya da yaşlanmayla birlikte dindarlığın ne şekilde değiştiğini tespit edebilmek için, bireylerin hayatlarının farklı evrelerindeki dindarlık seviyelerinin ölçüldüğü, panel verilere ihtiyaç vardır. Türkiye'de zaman serisi şeklinde yapılmış kapsamlı dindarlık araştırmaları mevcut olmadığından, bu araştırmanın sonuçlarını önceki yıllarla kıyaslamamız şu an için mümkün değildir.

Araştırmanın öne çıkan bulgularından bir diğeri ise, çalışma durumunun dindarlığın her üç ölçümü üzerindeki negatif etkisidir. Çalışmayanların çalışanlara göre daha yüksek dindarlık özdeğerlendirmesine sahip olduğu ve daha sık namaz kıldı̆̆g görülmektedir. İslam hukukundaki miras paylaşımına olumlu bakma olasılı̆̆ının da çalışanlara kıyasla çalışmayanlarda daha yüksek olduğu tespit edilmişsir. Araştırmada gelir düzeyi, eğitim durumu, yaş, cinsiyet faktörleri kontrol edildiğinden, çalışma durumu bu değişkenlerden bağımsız olarak dindarlık üzerinde bir etkiye sahiptir. Bunun alternatif birkaç izahı olabilir. Birincisi Weber'in rasyonelleşme argümanıdır. Buna göre, modern rasyonel prensipler üzerine kurulu olan çalışma hayatının çalışan insanları da rasyonelleştirerek dindarlıktan uzaklaştırdığı iddia edilebilir (Weber, 2013). Ancak Weber'in rasyonelleşme-din kıyaslaması, kendi içinde barındırdığı felsefi ve sosyolojik sorunlar bir yana, daha çok Hristiyanlığın ve özellikle Katolikliğin kutsaldünyevi dikotomisinden beslenmektedir. Toplumsal hayatta da karşıllı̆ı olacak şekilde, yatay olarak düzlemsel ve mekânsal ayrışmayı da ima eden bu ayrımın Müslüman toplumlar için de geçerli olduğunu söylemek kolay değildir.

Çalışmanın dindarlık üzerindeki negatif etkisi şehirlileşme üzerinden Durkheim'in sosyal dayanışma kuramlarına referansla da izah edilmeye çalışılabilir. Durkheim 
tarım ekonomisine dayalı modernite öncesi toplumlardaki mekanik iş bölümünde toplumsal fonksiyonu dolayısı ile dinin güçlü olduğunu, şehirleşme ile güçlenen organik dayanışmanın da dinin bu fonksiyonunu zayıflattığını vurgular (Durkheim, 2014). Hatta profesyonel iş ahlakının ve onun getirdiği ahlaki sorumlulukların, dinin yerini alabileceğini iddia eder. Bu durumda, çalışanların daha az dindar olmasının şehirlileşmenin etkisini dolaylı olarak yansıttığı iddia edilebilir. Ancak bu çalışmada kullanılan modeller kır-kent ayrımının etkisini de kontrol etmektedir. Dolayısı ile bireyin istihdama katılımının etkisini sadece şehirleşme ile izah etmek de mümkün değildir. Bir başka izah ise sosyalleşme ve sosyal baskıdır. Türkiye'de iş hayatı son y1llara kadar, özellikle kamuda, politik olarak daha çok seküler, hatta otoriter sekülerist olarak kurgulanmıştır. Bunun sonucu olarak, ağıllıkla seküler ortamlarda sosyalleşen ve otoriter sekülerizmin baskısını hisseden çalışanların, çalışmayanlara kıyasla daha az dindar oldukları iddia edilebilir. Ancak elimizdeki verilerden hareketle bu tür çıkarımlar yapmamız, metodolojik olarak mümkün değildir. Bu soruların daha yetkin bir şekilde cevaplanabilmesi için Türkiye'de iş hayatı ve dindarlık ilişkisine dair nitel yöntemlerin de kullanıldığı kapsamlı ve derinlemesine çalışmalara ihtiyaç vardır.

$\mathrm{Bu}$ çalışmanın öne çıkan bulgularından bir diğeri ise İslam hukukundaki miras paylaşımına bakışı etkileyen faktörlerin, dindarlık seviyesi ve namaz kılma sıklığını etkileyen faktörlerden farklılaşmasıdır. Çalışma bulgularına göre kadınlar, hem dindarlık öz değerlendirmesine hem de namaz kılma sıklığına bakıldığında erkeklerden daha dindarlardır. Miras paylaşımına bakışa göre değerlendirildiğinde ise erkeklere mirastan kadınların iki katı pay verilmesine, erkekler kadınlardan daha çok destek vermektedir. Erkeklerin kendi çıkarlarına daha yakın gördükleri anlayışı daha çok desteklemeleri doğrudan cinsiyet ile ilişkili olarak yorumlanabilir. Öte yandan, feminizm gibi kadın hakları hareketlerinin kadınların miras ve cinsiyet eşitliği hakkındaki düşüncelerini değiştirdiği de iddia edilebilir.

Cinsiyete benzer şekilde, kırsal alanlarda yaşayanlar öz değerlendirme ve namaz kılma sıklığında şehirlilere kıyasla daha dindar görünmektedir. Miras paylaşımına bakışta ise dinin öngördügü miras paylaşımına şehirde yaşayanlar, kırda yaşayanlardan daha fazla destek vermektedir. Bu bulgular öngörülebilir ve ilk başta akla gelebilecek sonuçlardan farklı görünmektedir. Zira genellikle kırda yaşayanların kentte yaşayanlara göre, gelenekselliğin yansitıcısı olduğu düşünülebilecek uygulamaları, daha çok kabul etmeleri beklenir. Geleneksel kadın-erkek arası ilişkiler bu uygulamalara dahildir. TDH araştırması verilerine bakarak, ilk bakışta akla gelebilecek sonuçlardan farklı olan bu sonuçları başka bir değişken veya değişkenler üzerinden izah etmek mümkün görünmese de sorulara verilen cevapta, sosyal kabul edilebilirlik önyargısının etkili olduğu düşünülebilir. Örneğin, "köylüler kadınlara eşit miras vermez" gibi bir stigmadan haberdar olan bazı katılımcıların, bu stigmanın tersi yönünde cevap vermiş oldukları düşünülebilir. Ancak, sosyal kabul edilebilirlik önyargısının, bu sonuçların ortaya 
çıkmasında etkili olup olmadığını mevcut veri seti ile cevaplamamız mümkün değildir. Bununla birlikte başka bir açıklama ise kırsal kesimde toprak paylaşımının refah için oldukça önemli olduğu ve miras paylaşımı sürecinde sıkıntı yaşayan insanların bu konuda duyarlılıklarının arttığı da söylenebilir. Doğrudan miras dağılımı uygulamalarına bakarak veya nitel araştırmalarla ile bu sorulara daha sağlıklı cevaplar edilebilir.

Araştırma sonuçlarından bir diğeri de mezhebin dindarlık üzerindeki belirgin etkisidir. Her üç ölçümde de Hanefi ve Şafiilerin diğer mezheplere göre daha dindar oldukları görülmektedir. Şafiiler dindarlık seviyesi en yüksek olan mezhep grubudur. Buradan, dolaylı olarak etnisitenin etkisine dair de yorum yapılabilir. Elimizdeki veri setinde katılımcıların etnisitelerine dair bir soru bulunmamaktadır. Ancak Türkiye'de Şafii mezhebine mensubiyetin Kürt vatandaşlar arasında yoğun olduğu göz önünde bulundurulursa, Kürt vatandaşların dindarlık seviyelerinin daha yüksek olduğu yorumu yapılabilir. Lakin bu, daha kapsamlı araştırmalarla teyit edilmeye muhtaç bir yorumdur.

Aile dindarlığının her üç dindarlık ölçümü üzerindeki pozitif etkisi, dindarlığın Türkiye'de de dünyanın diğer yerlerinde olduğu gibi, büyük ölçüde aileden intikal ettiğini göstermektedir. Zira beyan edilen aile dindarlığı yükseldikçe, katılımcıların kendi dindarlık seviyelerinde de artı̧̧ gözlemlenmektedir. Ancak burada rapor edilen aile dindarlık seviyeleri daha çok öznel değerlendirmeler ve toplu bildirimler olduğu için, aile dindarlık seviyeleri ve aile içindeki dindarlık farklılıkları hakkında tam olarak güvenilir bilgiler vermeyebilir. Ayrıca aile kavramı bazen çekirdek aile bazen de geniş aile ve akrabayı kapsayabileceği unutulmamalıdır. Örneğin, anne ve babanın ve bunlardan ayrı olarak geniş ailenin dindarlık seviyelerine dair veriler olması halinde, görece daha güvenilir çıarımlar yapabilmek mümkündür.

Öne çıkan bulgulardan bir diğeri ise eğitim ile dindarlık seviyeleri arasındaki ilişkinin doğrusal olmayışıdır. Örneğin, namaz kılma sıklığında en dindar olan grup hiç okula gitmemiş olanlar iken, en seyrek namaz kılanlar en yüksek eğitim seviyesinde olan üniversite mezunları değil, lise diplomasına sahip olanlardır. $\mathrm{Bu}$ farklılıklar eğitimin içeriğinden daha çok Türkiye'deki dindarlık ile sosyalleşme arasındaki güçlü ilişki ile izah edilebilir. İlkokul bitirmemiş olanların, sosyal mobilitesi daha az olabileceği için daha çok geleneksel ve dindar sosyal çevrelerde yetiştikleri ve çoğunlukla da bu geleneksel dindarlığı devam ettirdikleri söylenebilir. Üniversite mezunlarının lise mezunlarından daha çok namaz kılıyor olmaları ise Türkiye'de dini cemaat ve tarikatların daha çok üniversite öğrencileri üzerine yoğunlaşan faaliyet ve mobilizasyon stratejileri ile izah edilebilir. Ancak bu çıkarımın da niteliksel çalışmalar ve daha detaylı anket sorularından elde edilecek bilgilerle kontrol edilmesi gerekir.

$\mathrm{Bu}$ araştırmanın sınırlılıklarından biri, araştırmanın bağımlı değişkenlerinin toplumun genelinin dindarlığını ölçüp ölçemeyeceği ile ilgilidir. Ele alınan üç bağımlı 
değişkenden birincisi olan dindarlık öz değerlendirmesi, inanç grubu farklılıklarına bakılmaksızın hemen herkese uygulanabilecek bir sorudur. Zira hemen herkes, dini aidiyetinin olup olmaması veya herhangi bir din, mezhep veya ekol ile bağı olup olmamasına bakılmaksızın, ne kadar dindar olup olmadığına dair bir soruyu cevaplayabilir; bu soru üzerinden bireylerin değişik sosyal gruplar arasındaki dindarlık farklılıkları ele alınabilir. Ancak araştırmanın ikinci ve üçüncü bağımlı değişkenleri olan namaz kılma sıklığı ve İslam hukukundaki miras paylaşımına bakış ise daha çok İslam dinine mensup Sünni Müslümanlar için uygulanabilir sorulardır. Dolayısıyla, özellikle bu iki soru üzerinden yapılan analizlerin bu sınırlılı̆̆ının, göz önünde bulundurulması gerekmektedir. Ancak bu sinırlılık, yukarıda sunulan tablolardaki bulguların güvenilir olmadığı anlamına gelmez. Özellikle modellerde mezhep değişkenine yer verildiği, Hanefi ve Şafii dışındaki mezhepler referans grup olarak değerlendirmeye alındığı için; bulguların en azından bu iki mezhebe (Hanefi ve Şafii) mensup bireyler için daha güvenilir olduğu söylenebilir. Hanefi ve Şafiilerin de Türkiye nüfusunun büyük çoğunluğunu teşkil ettiği göz önüne alındığında, bu sonuçların Türkiye toplumu için büyük ölçüde güvenilir olduğu iddia edilebilir. Ancak bundan sonra ülke çapında yapılacak çalışmaların anket sorularının, diğer dini grupların (örneğin, Aleviler) dini pratiklerini de göz önünde bulunduracak şekilde hazırlanması araştırmacılara daha açıklayıcı ve genelleştirilebilir bulgular sunacaktır.

\footnotetext{
Hakem Değerlendirmesi: Dış bağımsız.

Çıkar Çatışması: Yazarlar çıkar çatışması bildirmemiştir.

Finansal Destek: Yazarlar bu çalışma için finansal destek almadığını beyan etmiştir.

Peer-review: Externally peer-reviewed.

Conflict of Interest: The authors have no conflict of interest to declare.

Grand Support: The authors declared that this study has received no financial support.
}

\section{Kaynakça/References}

Akın, H. B. ve Şentürk, E. (2012). Bireylerin mutluluk düzeylerinin ordinal lojistik regresyon analizi ile incelenmesi. Öneri Dergisi, 10(37), 183-193.

Akşit, B., Şentürk, R., Cengiz, K. ve Küçükural, Ö. (2012). Türkiye'de dindarlı: Sosyal gerilimler ekseninde inanç ve yaşam biçimleri. İstanbul: İletişim Yayınları.

Aktan, H. (1991). Mukayeseli İslam miras hukuku. İstanbul: İşaret Yayınları.

Albrecht, S. L., \& Heaton, T. B. (1984). Secularization, higher education, and religiosity. Review of Religious Research, 26(1), 43-58. https://doi.org/10.2307/3511041

Alston, J. P. (1975). Three measures of current levels of religiosity. Journal for the Scientific Study of Religion, 14(2), 165-168. https://doi.org/10.2307/1384739

Argue, A., Johnson, D. R., \& White L. K. (1999). Age and religiosity: Evidence from a three-wave panel analysis. Journal for the Scientific Study of Religion, 1, 423-435.

Arslan, M. (2003). Popüler Dindarlık Ölçeği’nin geliştirilmesi: Geçerlik ve güvenirlik çalışması. 
Dinbilimleri Akademik Araştırma Dergisi, 3(4), 97-116.

Brown, E., Orbuch, T. L., \& Bauermeister, J. A. (2008). Religiosity and marital stability among black American and white American couples. Family Relations, 57(2), 186-197. https://doi.org/10.1111/ j.1741-3729.2008.00493.x

Cornwall, M. (1989). Faith development of men and women over the life span. In S. J. Bahr \& E. T. Peterson (Eds.), Aging and the family (pp. 115-139). Lexington, MA, England: Lexington Books/D. C. Heath and Com.

Çarkoğlu, A. ve Toprak, B. (2000). Değişen Türkiye'de din, toplum ve siyaset. İstanbul: Türkiye Ekonomik ve Sosyal Etüdler Vakfi.

Çayabatmaz, E. (2016). Kur'an’ı Kerim bağlamında İslami Dindarlık Ölçeği denemesi (Yüksek lisans tezi, Erciyes Üniversitesi, Sosyal Bilimler Enstitüsü, Kayseri). https://tez.yok.gov.tr/ UlusalTezMerkezi/ adresinden edinilmiştir.

Davie, G. (2012). From believing without belonging to vicarious religion: Understanding the patterns of religion in modern Europe. In $\quad$ D. Pollack \& D. V.A. Olson (Eds.), The role of religion in modern societies (pp. 171-182). New York, NY: Routledge.

de Vaus, D., \& McAllister, I. (1987). Gender differences in religion: A test of the structural location theory. American Sociological Review, 52(4), 472-481. https://doi.org/10.2307/2095292

Diyanet İşleri Başkanlığı. (2014). Türkiye'de dini hayat araştırması. Ankara: Yazar.

Dudley, M. G., \& Kosinski, F. A. (1990). Religiosity and marital satisfaction: A research note. Review of Religious Research, 32(1), 78-86. https://doi.org/10.2307/3511329

Durkheim, E. (2014). The division of labor in society. New York, NY: Simon and Schuster.

Ellison, C. G., \& Levin, J. S. (1998). The religion-health connection: Evidence, theory, and future directions. Health Education \& Behavior, 25(6), 700-720. https://doi. org/10.1177/109019819802500603

Hunt, R. A., \& King, M. B. (1978). Religiosity and marriage. Journal for the Scientific Study of Religion, 17(4), 399-406. https://doi.org/10.2307/1385403

Hunsberger, B. (1978). The religiosity of college students: Stability and change over years at university. Journal for the Scientific Study of Religion, 17(2), 159-164. https://doi. org/10.2307/1386159

Gaunt, R. (2006). Couple similarity and marital satisfaction: Are similar spouses happier? Journal of Personality, 74(5), 1401-1420. https://doi.org/10.1111/j.1467-6494.2006.00414.x

Gerber, A. S., Gruber, J., \& Hungerman, D. M. (2016). Does church attendance cause people to vote? Using Blue Laws' repeal to estimate the effect of religiosity on voter turnout. British Journal of Political Science, 46(3), 481-500. https://doi.org/10.1017/S0007123414000416

Glock, C. Y. (1962). On the study of religious commitment. Religious Education, 57(4), 98-110. https://doi.org/10.1080/003440862057S407

Glock, C. Y., \& Rodney, S. (1965). Religion and society in tension (Pencil Margin Notes ed.). Rand McNally.

Heelas, P., Woodhead, L., Seel, B., Szerszynski, B., \& Tusting, K. (2005). The spiritual revolution: Why religion is giving way to spirituality. Oxford, UK: Blackwell.

Jones, A. E., \& Elliott, M. (2017). Examining social desirability in measures of religion and spirituality using the bogus pipeline. Review of Religious Research, 59(1), 47-64.

Kenney, B. P., Cromwell, R. E., \& Vaughan, C. E. (1977). Identifying the socio-contextual forms of religiosity among urban ethnic minority group members. Journal for the Scientific Study of 
Religion, 16(3), 237-244. https://doi.org/10.2307/1385694

Levin, J. S. (1994). Religion and health: Is there an association, is it valid, and is it causal? Social Science \& Medicine, 38(11), 1475-1482. https://doi.org/10.1016/0277-9536(94)90109-0

Miller, A. H., \& Wattenberg, M. P. (1984). Politics from the Pulpit: Religiosity and the 1980 Elections. Public Opinion Quarterly, 48(1B), 301-317. https://doi.org/10.1093/poq/48.1B.301

Malka, A., Lelkes, Y., Srivastava, S., Cohen, A. B., \& Miller, D. T. (2012). The association of religiosity and political conservatism: The role of political engagement. Political Psychology, 33(2), 275-299. https://doi.org/10.1111/j.1467-9221.2012.00875.x

Nudelman, A. E. (1971). Dimensions of religiosity: A factor-analytic view of Protestants, Catholics, and Christian scientists. Review of Religious Research, 13(1), 42-56. https://doi. org $/ 10.2307 / 3510323$

Ok, Ü. (2011). Dini Tutum Ölçeği: Ölçek geliştirme ve geçerlik çalışması. Uluslararası İnsan Bilimleri Dergisi, 8(2), 528-549.

Özer, G., Özbek, V., Elçi, M., \& Aydın, K. (2015). Concurrent validity of different religiosity scales used in researches of marketing ethics and a proposal for a new religiosity scale, Anadolu Üniversitesi Sosyal Bilimler Dergisi, 13(4), 15-28.

Park, J. Z., \& Smith, C. (2000). “To whom much has been given...”: Religious capital and community voluntarism among churchgoing Protestants. Journal for the Scientific Study of Religion, 39(3), 272-286.

Shehan, C., Wilbur Bock, E., \& R. Lee, G. (1990). Religious heterogamy, religiosity, and marital happiness: The case of Catholics. Journal of Marriage and the Family, 52, 73-79. https://doi. org/10.2307/352839

Smidt, C. (1999). Religion and civic engagement: A comparative analysis. The ANNALS of the American Academy of Political and Social Science, 565(1), 176-192. https://doi. org/10.1177/000271629956500112

Smith, L. E., \& Walker, L. D. (2013). Belonging, believing, and group behavior: Religiosity and voting in American presidential elections. Political Research Quarterly, 66(2), 399-413. https:// doi.org/10.1177/1065912912443873

Taniguchi, H., \& Thomas, L. D. (2011). The influences of religious attitudes on volunteering. Voluntas: International Journal of Voluntary and Nonprofit Organizations, 22(2), 335-355.

Taplamacıŏglu, M. (1962). Yaşlara göre dinî yaşantının şiddet ve kesafeti üzerinde bir anket denemesi. Ankara Üniversitesi İlahiyat Fakültesi Dergisi, 10, 141-151.

Tosuner, M. ve Demir, C. İ. (2008). Ege Bölgesi’nin vergi ahlak düzeyi. Afyon Kocatepe Üniversitesi İktisadi ve İdari Bilimler Fakültesi Dergisi, 10(2), 355-373.

Wallace, J. M., Jr., \& Williams, D. R. (1997). Religion and adolescent health-compromising behavior. In J. Schulenberg, J. L. Maggs, \& K. Hurrelmann (Eds.), Health risks and developmental transitions during adolescence (pp. 444-468). New York, NY, US: Cambridge University Press.

Weber, M. (2013). The Protestant ethic and the spirit of capitalism. New York, NY: Routledge.

Weigert, A. J., \& Thomas, D. L. (1970). Socialization and religiosity: A cross-national analysis of Catholic adolescents. Sociometry, 33, 305-326. https://doi.org/10.2307/2786160

Wilkes, R. E., Burnett, J. J., \& Howell, R. D. (1986). On the meaning and measurement of religiosity in consumer research. Journal of the Academy of Marketing Science, 14(1), 47-56. https://doi. org/10.1007/BF02722112 
Willits, F. K., \& Crider, D. M. (1988). Religion and well-being: Men and women in the middle years. Review of Religious Research, 29(3), 281-294. https://doi.org/10.2307/3511225

Wuthnow, R. (1999). Mobilizing civic engagement: The changing impact of religious involvement. In T. Skocpol \& M. Fiorina (Eds.), Civil engagement in American democracy (pp. 331-364). Washington, DC: Brookings Institution Press.

Wuthnow, R., \& Hodgkinson, V. A. (1990). Faith and philanthropy in America: Exploring the role of religion in America's voluntary sector. San Francisco: Jossey-Bass.

Yeung, A. B. (2004). An intricate triangle - Religiosity, volunteering, and social capital: The European perspective, the case of Finland. Nonprofit and Voluntary Sector Quarterly, 33(3), 401-422. https://doi.org/10.1177/0899764004265426

Yapıcı, A. (2006). Yeni Bir Dindarlık Ölçeği ve üniversiteli gençlerin dinin etkisini hissetme düzeyi: Çukurova Üniversitesi örneği. Çukurova Üniversitesi İlahiyat Fakültesi Dergisi, 6(1), 5-38.

Yılmaz, H. (2006). Türkiye'de muhafazakarlık: Aile, din, devlet, cinsiyet (Yayımlanmamış Araştırma Raporu).

Young, G., \& Dowling, W. (1987). Dimensions of religiosity in old age: Accounting for variation in types of participation. Journal of Gerontology, 42(4), 376-380. https://doi.org/10.1093/ geronj/42.4.376 
